УДК 001.895

\title{
АНАЛИЗ ИННОВАЦИОННОЙ АКТИВНОСТИ ПРЕДПРИЯТИЙ
}

\section{О.В. МАШЕВСКАЯ}

ст. преподаватель кафедры права и экономических теорий

Белорусский торгово-экономический университет потребительской кооперации, г. Гомель

\begin{abstract}
Аннотация
Раскрыта сущңность инноваций, представлена к рассмотрению характеристика инноваций и их особенности в рамках жизненного иикла. Установлено, что в сложившихся условиях возрастает роль инноваций,как на мировом, так и на межрегиональном рынке, а значит, усиливается актуальность выработки адекватной инновационной политики. Проведен анализ инноваџионной активности на микроуровне (предприятий) в Республике Беларусь и России, дана оценка их масштабов деятельности и предложены направления совершенствования и разработки инноваций.
\end{abstract}

\section{Abstract}

In article the essence of innovations is opened, the characteristic of innovations and their feature at stages of life cycle is considered. We found out that the role of innovations in world and in the interregional market at this conjuncture increases. Therefore, relevance of development of innovative policy amplifies. The analysis of innovative activity at the microlevel (enterprises) in the Republic of Belarus and theRussia is carried out, the assessment of their scales of activity is given and the directions of improvement and development of innovations are offered.

\section{ВВЕДЕНИЕ}

Главную роль в становлении модели экономического роста должен играть перевод научно-промышленного потенциала страны на инновационный путь развития.

Инновации в национальной экономике являются едва ли не главным фактором конкурентоспособности предприятия. В свою очередь конкурентоспособность становится ключевым фактором обеспечения экономической безопасности хозяйственной системы и ее устойчивого развития. Поэтому переход на инновационную модель развития это приоритет не только государственного значения, но и объективно существующая потребность функционирующего в рыночных условиях предприятия любой формы собственности. Цель предприятия заключается не только в выполнении количественных показателей, достижении производственно-экономической эффективности и соблюдении стабильности эффекта масштаба, но и в выполнении качественных показателей, достижении социальной эффективности при способности предприятия создавать возможности для изменений, стартовые площадки для нововведений и возможность продуцировать следующий уровень инноваций. Это делает особенно актуальным проблемы повышения инновационной активности предприятий, для которых характерна недостаточность теоретического осмысления целого комплекса связанных с данной проблематикой вопросов.

\section{РЕЗУЛЬТАТЫ И ИХ ОБСУЖДЕНИЕ}

Теория вопроса. В современных условиях глобализации и интеграции, достаточно жесткой конкурентной борьбы, результирующая деятельность предприятий становится предметом внимания, исследований и дискуссий. Чтобы предприятие не выживало на рынке, а эффективно функционировало и динамично развивалось, необходимы инновации. Инновации являются своего рода катализатором любой деятельности.

Раскроем сущность инновации посредством ее качественной характеристики.

Таблица 1 - Качественная характеристика категории «инновация»

\begin{tabular}{|c|c|}
\hline $\begin{array}{l}\text { Содержание } \\
\text { инноваций }\end{array}$ & $\begin{array}{l}\text { Производственно-организационный процесс, инициированный специализированными } \\
\text { научно-исследовательскими институтами, с универсальными методами и набором ин- } \\
\text { струментов, развивающийся по объективным законам, характеризующийся своеобразным } \\
\text { жизненным циклом, направленный на создание и освоение новых технологий, новых под- } \\
\text { ходов к управлению, новых видов продуктов/услуг, заключающих в себе качественно но- } \\
\text { вую экономическую полезность }\end{array}$ \\
\hline Цель & $\begin{array}{l}\text { Достижение максимальной производительности труда и интеллектуализации производ- } \\
\text { ства при минимуме человеческого и вещественного капитала }\end{array}$ \\
\hline Задачи & $\begin{array}{l}\text { 1. Максимальное использование конкурентных преимуществ; } \\
2 . \\
\text { бинаций. }\end{array}$ \\
\hline $\begin{array}{l}\text { Механизм } \\
\text { инноваций }\end{array}$ & $\begin{array}{l}\text { Опосредуется через стратегическое управление инновационной деятельностью по } \\
\text { средствам организационной, контролирующей, координирующей и мотивационной функ- } \\
\text { ций с учетом кадровой, финансовой, производственной, инвестиционной компонент в } \\
\text { рамках упорядоченных бизнес-процессов }\end{array}$ \\
\hline
\end{tabular}




\begin{tabular}{|c|c|}
\hline $\begin{array}{l}\text { Направления реализа- } \\
\text { ции инноваций }\end{array}$ & $\begin{array}{l}\text { а) горизонтальный аспект; } \\
\text { б) вертикальный аспект. }\end{array}$ \\
\hline $\begin{array}{l}\text { Предполагаемые виды } \\
\text { инноваций }\end{array}$ & $\begin{array}{l}\text { а) реальные инновации - это нововведения, внедряемые и реализуемые предприя- } \\
\text { тием в текущих условиях при данных ресурсах; } \\
\text { б) потенциальные инновации - инновации, которые могло бы внедрить и реализо- } \\
\text { вать предприятие при более эффективном использовании имеющихся ресурсов и обнов- } \\
\text { лении парка технологий; } \\
\text { г) стратегические инновации - инновации, на внедрение которых нацелено пред- } \\
\text { приятие в будущем при условии постоянной модернизации производства, повышение ква- } \\
\text { лификации кадрового состава и вливании инвестиций. }\end{array}$ \\
\hline Результат & $\begin{array}{l}\text { Стимулирует обновления перечня выпускаемой продукции, улучшает качества и по- } \\
\text { требительские свойства товара/услуг с целью удовлетворения потребностей потребителей } \\
\text { и максимизации прибыли с целью удовлетворения потребностей производителей }\end{array}$ \\
\hline
\end{tabular}

Источник: собственная разработка

Вид и характер внедряемых инноваций зависит часто от рода деятельности предприятия, его отраслевой направленности. Однако всем инновациям присущ жизненный цикл, под которым следует понимать период времени от момента внедрения инновации в производство, его коммерциализации на рынке, т.е. признание покупателями, до момента прекращения производства и исчезновения с рынка.

С научной точки зрения существует два подхода к пониманию жизненного цикла инноваций. Одни ученые считают, что период жизненного цикла инновации начинается с разработки фундаментальных исследований НИР в данной области и заканчивается диффузией инноваций (сбытом) [1]. Другая группа ученых полагает, что жизненный цикл инновации охватывает период времени от фазы ее внедрения до фазы превращения в традиционный продукт [2].

Инновация реализуется в товаре, который характеризуется максимальной скоростью изменения продаж на стадии зарождения, внедрения и спада, и минимальной скоростью - на стадии насыщения и зрелости. В рамках концепции жизненного цикла инноваций можно наблюдать не только за динамикой инноваций, но и за динамикой роста прибыли (рисунок 1). Положительная динамика прибыли возможна на стадиях роста, зрелости и насыщения.

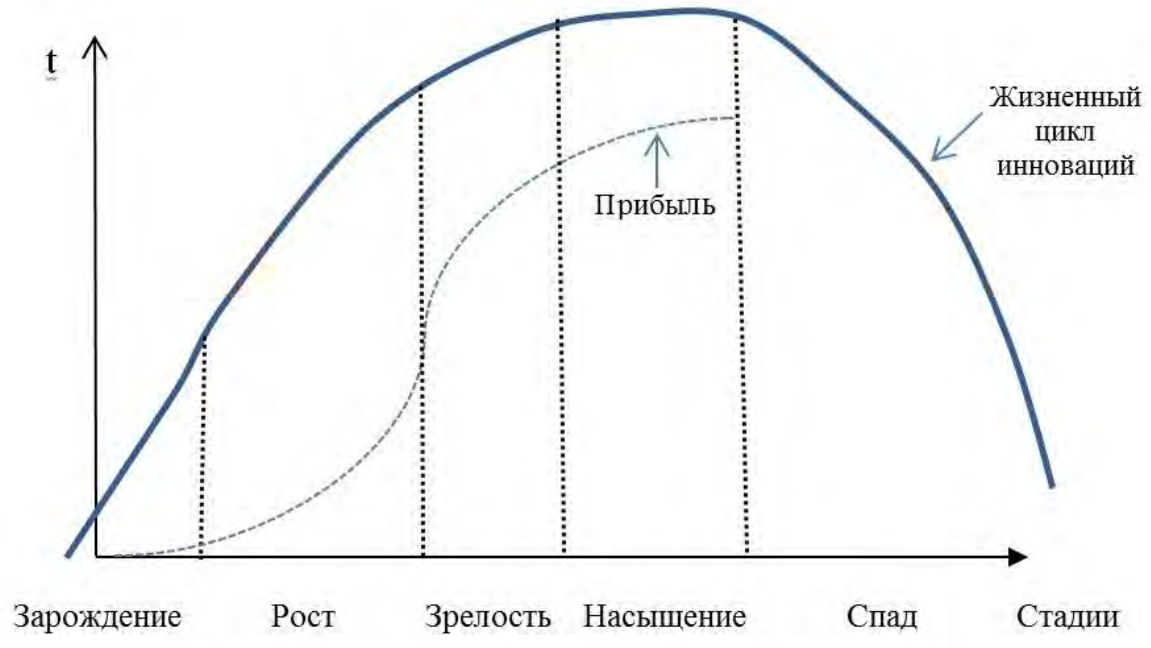

Рисунок 1 - Стадии жизненного цикла инноваций и прибыли

Жизненный цикл инновации - это фактически востребованный рыночный период функционированияреализованной в товаре инновации. Параметры жизненного цикла инновации изменяются на стадиях, но могут меняться и внутри периодов, что связано с рыночными тенденциями. Подобные деформации логистических кривых происходят в реальных рыночных структурах.

Модель жизненного цикла инноваций может быть представлена в обобщённом виде при введении определенных условий и некоторых ограничений с целью получения определенного его вида, который бы не зависел от формального вида рыночной структуры. Одним из таких условий является стабильная макроэкономическая среда или внешнее окружение, при которой сохраняется общая тенденция роста реального объема производства, обусловленного последовательным расширением экономической системы в темпах, соответствующих ее внутренним возможностям. Несоблюдение данного условия оценки динамики жизненного цикла инноваций и формы их кривой может привести к неверным выводам относительно границ стадий. Например, условия кризисов меняют традиционную форму кривой жизненных циклов большинства видов продукции, в том числе, находившихся на ранних стадиях, искажают поведение покупателей, имеющих низкую платежеспособность, деформируют реакцию конкурентов. 
Рассмотрим стадии инноваций. Стадия внедрения инноваций характеризуется низкой скоростью увеличения продаж. Графически это выглядит как малый угол наклона кривой продаж к оси времени (t), а математически - малое значение кривой производной функциональной зависимости продаж от времени (рисунок 1).

Одним из факторов низкой скорости увеличения продаж выступает цена, инициированная высокими начальными издержками. В соответствие с законом спроса на инновационную продукцию при значительной цене объем продаж будет не большим. Предприятие на стадии внедрения ограничено в выборе ценовой стратегии, и в то же время существует высокая ценовая эластичность по сравнению с другими стадиями на любом сегменте рынка. То есть наблюдается высокая ценовая эластичность продаж на стадии внедрения. Данная стадия характеризуется новой продукцией предприятия и ее конкурентным статусом на рынке. В краткосрочном периоде производство данного вида инновационной продукции является убыточным, а покрытие издержек осуществляется за счет производства рентабельных продуктов предприятия. Одновременно с исследованием и разработкой инновации, перед ее выведением на рынок осуществляется расчет ожидаемой экономической эффективности дополнительных вложений, где критерием в общем объеме вложений является банковская процентная ставка и/или альтернативная (максимально возможная) величина доходов, которые могли быть получены из других источников размещения этих денежных средств.

Экономической причиной низкой динамики продаж является медленное вовлечение в процесс производства всех основных факторов из-за технических проблем модернизации оборудования, организационной и квалификационной адаптации персонала к инновационному виду продукции. Имеет значение также психологический фактор высокой ответственности, а значит, осторожности, обусловленной наличием определенного риска несовпадения прогнозируемого и реального восприятия потребителями нового товара.

Следующая стадия - это стадия роста. Инновации получили признание в продукте и становятся востребованными на рынке. На данной стадии увеличивается скорость продаж продукции, а это отражается на конфигурации кривой жизненного цикла, т.е. наличием вогнутости кривой жизненного цикла на границе стадий внедрения и роста. На границе стадии роста МС (предельные издержки) имеют минимальное значение, а их динамика изменяется в сторону увеличения. АТС (средние издержки) на данной стадии продолжают снижаться: 1) за счет уменьшения удельного веса постоянных издержек в общем объеме затрат; 2) за счет сокращения норм расхода ресурсов, что обусловливает уменьшение переменных издержек в общем объеме средних издержек.

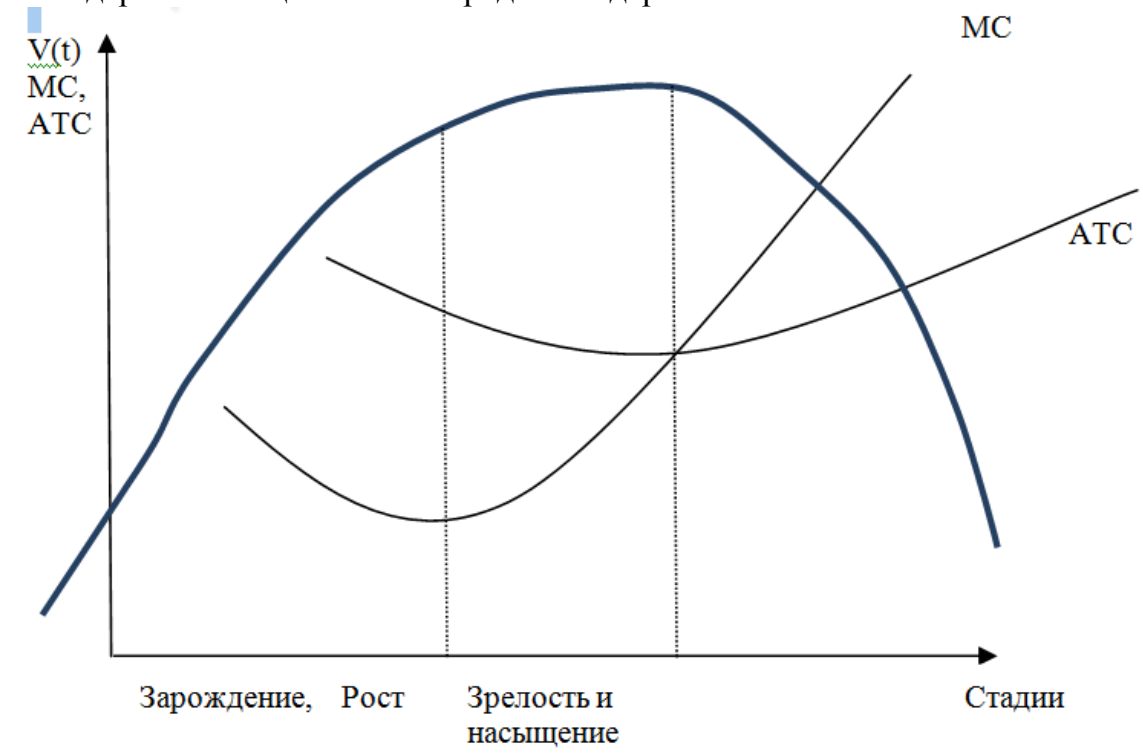

Рисунок 2 - Динамка жизненного цикла инновации, воплощенной в товаре v(t), средних издержек (АТС) и предельных издержек (МC)

Инновации связаны с разработкой и внедрением на рынок принципиально новой продукции, имеющей лишь косвенные или отдаленные заменители (субституты), что потребует от производителя усилий по ее узнаваемости покупателем и достаточных издержек на освоение и переход в пользование. Степень адаптации потребителей к инновации является самой низкой на данной стадии цикла и зависит от степени удовлетворения потребностей потребителей.

Замедление скорости продаж инновации на стадии зрелости и насыщения (рисунок 2) графически представлено как кривая функции продаж от времени с незначительно возрастающей динамикой. На границе стадии насыщения кривая имеет точку изгиба. Граница стадий зрелости и насыщения, а так же точка изгиба жизненного цикла инноваций, соответствует равенству средних издержек и предельных (АТС=MC). Предприятию не выгоден дальнейший рост продаж без принципиальных изменений технологий, организации производства, повышения эффективности управления предприятием, обуславливающих снижение средних издержек. Потенциальные резервы экономии ресурсов при существующей технологии полностью использованы к началу стадии насыщения жизненного цикла. Любое увеличение продаж ведет к росту предельных издержек (МС) относительно средних издержек (АТС), что будет способствовать сокращению прибыли предприятия (Pr).

Динамику продаж на стадии насыщения жизненного цикла можно объяснить на основе функции спроса. При условии, что характеристики потребительских свойств предложенного инновационного товара больше не будут усо- 
вершенствоваться, функция спроса будет зависеть от таких переменных как цена и расходы на рекламу. Снизать цену для стимулирования продаж при одновременном росте расходов на рекламу невозможно, поскольку расходы на рекламу будут способствовать росту АТС. Снижение цены ограничивается возрастающими издержками, причем темпы роста МС опережают темпы роста АТС, а низкая эластичность спроса на стадии зрелости делает малоэффективными любые изменения цены.

В конце жизненного цикла инновация теряет свою привлекательность, а у предприятия появляется потребность в получении доступа к следующей инновации, способной опять обеспечить предприятию конкурентные преимущества, при этом потребность в новой инновации может появиться еще до ухода с рынка предыдущей инновации.

На динамику жизненного цикла инноваций влияют многочисленные макроэкономические факторы. Это факторы товарного рынка, имеющие отношения к определенному виду экономической деятельности, а также факторы и условия производственно-коммерческой, сервисной и инновационной деятельности рассматриваемого предприятия. Совокупность перечисленных факторов формирует конкурентные преимущества предприятия по отношению к действиям конкурентов:

а) конкурентные преимущества с низкой степенью устойчивости, т.е. доступны конкурентам без особых финансовых и материальных усилий;

б) конкурентные преимущества со средней степенью устойчивости, т.е. лидирующие позиции предприятие будет удерживать некоторое время, что будет обеспечиваться за счет производства инновационной продукции, запатентованных нововведений и др.;

в) конкурентные преимущества с высокой степенью устойчивости обеспечиваются за счет больших инвестиций, сопровождающихся высоким качеством их реализации [4].

Итак, теоретическое исследование приводит нас к мысли, что:

1.Жизненный цикл позволяет продлить период роста производства до некоторой точки изгиба, которой в математическом выражении соответствуют показатели экономической эффективности.

2.Следует установить зависимость между ростом выпуска инновационной продукции с точками максимума экономических показателей и объемом затрат на их разработку, внедрение и реализацию с целью определения наличия (или отсутствия) пропорциональности и эффекта запаздывания [5].

Подобный анализ мы проведем ниже.

Повышение конкурентной борьбы в современном мире наблюдаются не только на мировом рынке, но и на межрегиональных рынках. При этом конкурентоспособность последних определяется научно-технологическим потенциалом, инновационной активностью предприятий и способностью привлекать внешние ресурсы для собственного инновационного развития. Проанализируем перечисленные выше критерии на примере России и Беларуси.

Таблица 1 - Место Беларуси и России в рейтингах стран мира

\begin{tabular}{|c|c|c|c|c|}
\hline Рейтинг & $\begin{array}{c}\text { Количество стран, при- } \\
\text { нявших участие в по- } \\
\text { следнем исследовании } \\
\text { (2012-2014 гг.) }\end{array}$ & $\begin{array}{c}\text { Беларусь } \\
\text { (место в рей- } \\
\text { тинге) }\end{array}$ & Первое место & $\begin{array}{c}\text { Россия } \\
\text { (место в } \\
\text { рейтинге) }\end{array}$ \\
\hline $\begin{array}{c}\text { Индекс развития человече- } \\
\text { ского потенциала }\end{array}$ & 186 & 50 & $\begin{array}{c}\text { Норвегия,Австралия, } \\
\text { США }\end{array}$ & 55 \\
\hline $\begin{array}{c}\text { Индекс экономической сво- } \\
\text { боды }\end{array}$ & 178 & 150 & $\begin{array}{c}\text { Гонконг, } \\
\text { Сингапур, } \\
\text { Австралия }\end{array}$ & 140 \\
\hline $\begin{array}{c}\text { Рейтинг стран по легкости } \\
\text { ведения бизнеса }\end{array}$ & 189 & 63 & $\begin{array}{c}\text { Сингапур, Гонконг, Новая } \\
\text { Зеландия }\end{array}$ & 92 \\
\hline $\begin{array}{c}\text { Рейтинг глобальной кон- } \\
\text { курентоспособности 2013- } \\
2014 \\
\end{array}$ & 148 & $\begin{array}{c}\text { не } \\
\text { yuacmsyem }\end{array}$ & $\begin{array}{l}\text { Швейцария, } \\
\text { Сингапур, } \\
\text { Финляндия }\end{array}$ & 64 \\
\hline $\begin{array}{c}\text { Глобальный индекс инно- } \\
\text { ваций } \\
\end{array}$ & 142 & 77 & $\begin{array}{c}\text { Швейцария,Швеция, } \\
\text { Великобритания }\end{array}$ & 62 \\
\hline Качество госуправления & 215 & $5-37$ & & $13-39$ \\
\hline Индекс процветания & 142 & 58 & $\begin{array}{l}\text { Норвегия,Швейцария, } \\
\text { Канада }\end{array}$ & 61 \\
\hline Индекс экономики знаний & 146 & 59 & $\begin{array}{c}\text { Швеция,Финляндия, } \\
\text { Дания }\end{array}$ & 55 \\
\hline $\begin{array}{c}\text { Кредитные рейтинги } \\
\text { Moody's }\end{array}$ & - & B3 & $\begin{array}{c}\text { Германия, Канада, Швей- } \\
\text { цария (Ааа) }\end{array}$ & Baa1 \\
\hline $\begin{array}{c}\text { Суверенный кредитный } \\
\text { рейтинг от Standard\&Poor's }\end{array}$ & - & $B-$ & $\begin{array}{c}\text { Великобритания, Герма- } \\
\text { ния, Канада (ААА) }\end{array}$ & $\mathrm{BBB}$ \\
\hline
\end{tabular}

Источник: Информационно - аналитическая записка «Об итогах социально-экономического развития Республики Беларусь за 2013 годи мерах по повышению конкурентоспособности экономики», Минск, 2014. - с. 15 
Согласно данным Отчета ООН Беларусь в 2014 году заняла 50 место по Индексу развития человеческого потенщиала, поднявшись на 15 позиций по сравнению с результатом прошлого года. Россия в данном рейтинге находится на пять позиций ниже, и занимает 55 место. По значению ИРЧП Республика Беларусь и Россия, как и ранее, относятся к странам с высоким уровнем человеческого развития. Увеличение значения ИРЧП и улучшение позиции рассматриваемых стран в международном рейтинге было вызвано ростом ряда значений компонентов ИРЧП: ожидаемой продолжительности жизни при рождении (с 70,3 лет до 70,6 лет), ожидаемой продолжительности обучения (с 14,6 лет до 14,7 лет). Особый прогресс в Беларуси отмечен по показателю средней продолжительности обучения (с 9,3 лет до 11,5 лет). В рейтинге же стран по объему валового национального дохода (ВНД) на душу населения (в долларах США по паритету покупательной способности) Беларусь занимает 61 место, при этом демонстрируя некоторый регресс.

Беларусь улучшила свое положение в рейтинге по общему индексу легкости ведения бизнеса «Ведение бизнеса-2014: понимание регулирования деятельности малых и средних предприятий» на одну позицию и заняла 63-е место среди 189 стран, что должно положительно отражаться на динамике роста инноваций в производстве. Россия находится на 92 месте (+19 позиций).

Менее позитивен прогресс в реализации задачи по достижению 70 места в Индексе экономической свободыл. Согласно исследованию американского Фонда наследия (TheHeritageFoundation) и американского журнала для деловых кругов TheWallStreetJournal, в очередном рейтинге по сравнению с 2012 г. оценка Беларуси улучшилась на 4 позиции до 150 строки рейтинга (ранее страна занимала 154-е место из 177 - ми). Однако республика остается в категории стран с негативной оценкой экономической свободы и традиционно находится не выше 150 места. Россия заняла позицию в рейтинге на 140 месте.

Служба кредитных рейтингов международного рейтингового агентства Standard\&Poor's /S\&P/ изменила прогноз по долгосрочным кредитным рейтингам по обязательствам в иностранной и национальной валюте Беларуси с «позитивного» на «стабильный». В то же время S\&P подтвердило долгосрочные и краткосрочные суверенные рейтинги страны по обязательствам в иностранной и национальной валюте на уровне «В/В». В России данный показатель находится на уровне ВBB. В сообщении $S \& P$ отмечается: «Пересмотр прогноза отражает наше мнение о том, что вероятность повышения рейтингов Беларуси в ближайшие 12 месяцев более не оценивается как один $к$ трем. Ухудшение внешнеэкономических показателей страны и усиление давления на валютный курс обуславливают значительную уязвимость внешнеэкономической позиции республики» [6].

Что касается глобального индекса инноваций, то из 142 стран рейтинга, Россия находится на 62 месте, опережая Беларусь на 15 стран (77 место в рейтинге). Позиции по индексу инноваций должны стимулировать общий объем ВВП. Предполагается, что совокупный ВВП 28 стран ЕС, согласно докладу WorldEconomicOutlook (WEO) МВФ, в 2015 году должен увеличится на 3,9 \%. В ЕС после двух лет рецессии и стагнации, вызванных долговым кризисом, который вынудил практически все государства пойти на жесткие меры бюджетной экономии, начинается подъем, хотя и не очень быстрый.

Действительно, примерно с лета 2013 года статистика фиксирует во многих странах Евросоюза постепенное улучшение макроэкономических показателей. Они касались, прежде всего, двух основных «стран-источников роста» - Германии и Великобритании.

Что касается российской экономики, то здесь ситуация несколько иная. Так, в прошедшем 2014 году объем ВВП РФ за 2014 год, по предварительной оценке Росстата, составил в текущих ценах 70 трлн. 975,6 млрд. рублей. Темпы роста экономики в 2014 году стали минимальными с 2009 года. В 2012 году ВВП России вырос на 3,4\%, в 2011 году - на 4,3\%, в 2010 году - на 4,5\%. В кризисном 2009 году экономика РФ упала на 7,8\%. Такие показатели снижения ВВП могут отрицательно сказаться на инновационной динамике экономике России [7].

Таким образом, прогнозы для экономики торгово-экономических партнеров Беларуси на 2015 год не достаточно удовлетворительные, что возможно, скажется и на инновационной составляющей экономике самой Беларуси. Всемирный банк прогнозирует рост ВВП Беларуси в 2015 году на уровне 1,8\%, в 2016 году белорусский ВВП, по их прогнозам, должен вырасти на 2\%, такой же рост он продемонстрирует и в 2017-м [8]. Эксперты отметили, что в 2014 году экономический рост в Беларуси был вялым и отражал сокращение экспорта, волатильную экономическую политику и отсутствие структурных реформ, что мешало росту конкурентоспособности экономики. В результате правительство Беларуси пересмотрело прогноз социально-экономического развития страны в 2015 году, снизив показатель роста ВВП с 2 \% до 0,2-0,7 \%, что было отмечено 22 ноября 2014 года на заседании Совета Министров Республики[9].

В рамках ВВП для оценки инновационного потенциала страны анализируются данные наукоемкости ВВП. По данным правительства, прогнозируемый на 2015 год уровень наукоёмкости ВВП составит 2,5-2,9\%. Такой уровень (если он будет достигнут), будет соответствовать показателям стран - лидеров. Однако представленные в открытой печати данные показывают, что величина наукоемкости ВВП Беларуси за последние 15 лет находится в пределах 0,641,09\%. Для роста показателя наукоемкости важно увеличить исследовательскую составляющую в расходовании средств инновационных фондов, а также использовать механизмы государственно-частного партнерства в инновационной сфере.

Перспективы может иметь создание смешанных инновационно активных предприятий с участием государства (вклад - предоставление прав на принадлежащие государству объекты интеллектуальной собственности) и бизнеса (вклад - материально - техническое обеспечение, ресурсы на коммерциализацию ОИС, проведение новых исследований).

Однако, как показывает практика, государство не увеличивает, а иногда сокращает расходы на инновационную 
деятельность. Например, Законом Республики Беларусь от 26 октября 2012 года № 432-3 «О республиканском бюджете на 2013 год» расходы республиканского бюджета на научную, научно - техническую и инновационную деятельность предусмотрены в сумме 2.313.213.000 тыс. рублей. А затем в соответствии с Указом Президента Республики Беларусь от 28 декабря 2013 года № 576 «Об уточнении отдельных показателей республиканского бюджета на 2013 год и внесении изменений в Указ Президента Республики Беларусь от 14 марта 2013 года № 126» расходы бюджета на данные цели были уменьшены на 254.040.244,9 тыс. рублей.

Ограниченность средств, а также необходимость вовлечения средств бизнеса, особенно малых и средних предприятий, в выполнение НИОКР требуют новых подходов при оказании государственной поддержки. Она должна направляться на финансирование комплексных междисциплинарных исследований, совместно выполняемых организациями академической, вузовской и отраслевой науки, ориентированных на последующее создание высокотехнологичных предприятий с продукцией (работами, услугами) высшего мирового уровня конкурентоспособности.

Вступили в действие нормы Указа Президента Республики Беларусь от 4 февраля2013 г. № 59 «О коммерциализации результатов научной и научно-технической деятельности, созданных за счет государственных средств», по которым нарабатывается правоприменительная практика. В настоящий момент в составе факторов, сдерживающих коммерциализацию результатов научно-технической деятельности, можно указать следующие:

- недостаточный уровень менеджмента и продвижения наукоемкой высокотехнологичной продукции на рынок;

- наличие ограничений прав на использование результатов научно-технической деятельности, полученных в рамках договоров на выполнение НИОКР;

- недостаточное количество организаций и квалифицированных кадров, обеспечивающих процессы трансфера технологий;

ных с инновационной деятельностью [10].

По итогам 2013 года (как и в 2012 году) обеспечено выполнение прогнозного параметра инновационного развития. Удельный вес инновационной продукции, отгруженной в 2013 году организациями, основным видом экономической деятельности которых является производство промышленной продукции, в общем объеме отгруженной продукции промышленности, за год практически не изменился и составил 17,8\% (в 2012 году - 17,9\%). Несмотря на выполнения целевого параметра 2013 года, доля отгруженной инновационной продукции пока находится ниже порога научно-технологической безопасности - 20\%, определенного Концепцией национальной безопасности. Достижение значения этого показателя на уровне 20-21\% предусмотрено Государственной программой инновационного развития к 2015 году, что в условиях нарастания темпов научно-технического прогресса и обострения конкуренции не позволяет рассчитывать на сокращение разрыва со странами-лидерами.

С сожалением стоит констатировать сокращение показателей, отражающих число организаций в Беларуси, выполнявших научные исследования и разработки по секторам деятельности (таблица 2), чего не скажешь о динамике показателей по России, которые указывают на рост всех значений, за исключением сектора коммерческих организаций (предпринимательский сектор).

Таблица 2 - Число организаций, выполнявших научные исследования и разработки, по секторам деятельности

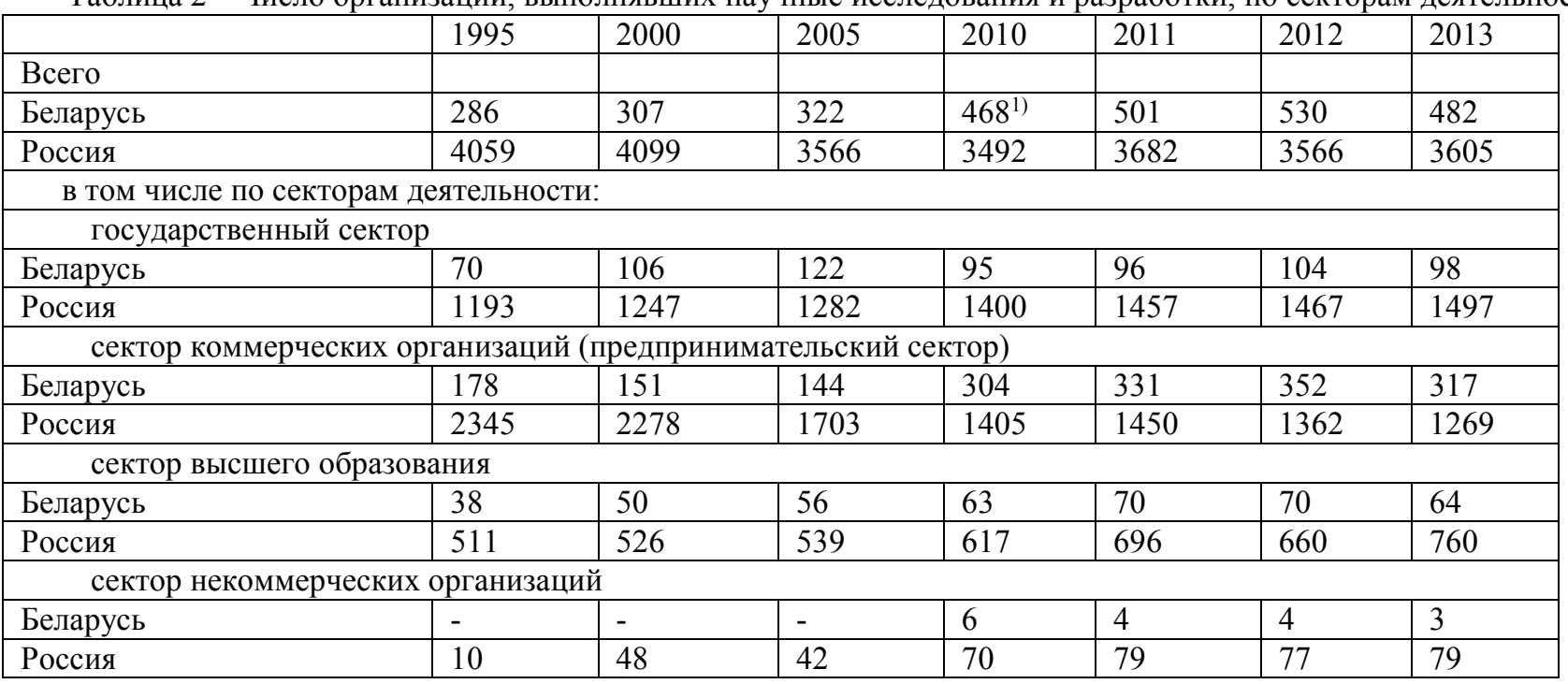

С 2009 г. - включая данные по малым и микроорганизациям.

Источник: Беларусь и Россия. Статистический сборник. - [Электронный ресурс]. -1995-2013. - Режим доступа : http://www.gks.ru/bgd/regl/b14_37/Main.htm Дата доступа : 10.06.2015

Отрицательная динамика показателей по Беларуси должна быть компенсирована значительной поддержкой правительства в инновационном процессе и направлена: 
1) на мотивацию отдельных предприятий или отраслей, занятых инновационной деятельностью путем распространения стимулирующей информацией, обучения, консультирования и материального финансирования;

2) на возможность связывать промышленность с инновационными идеями, партёрами, опытом;

3) на возможность предоставлять ресурсы по управлению инновационными проектами и опыт, необходимый для развития высокоприоритетных инноваций [12, с. 26-27].

Таким образом, тенденции последних лет в инновационной сфере сохранили свою актуальность и в 2013-2014 гг. До конца пятилетия необходимо преодолеть отдельные негативные тенденции, сопровождающие преимущественно эволюционные процессы формирования белорусской модели инновационной экономики. Предстоит завершить создание полномасштабной системы рамочных условий успешной инновационной деятельности. Важно преодолеть недостаточность, по сравнению со странами-лидерами, абсолютной величины расходов государства на исследования и разработки. При этом необходимо задействовать в полную силу стимулы для полноценного участия отраслей и бизнес-сектора в развитии науки, завершить формирование рынка объектов интеллектуальной собственности и системы продвижения результатов НИОКР из науки в производство. Для этой цели, можно перенять опыт европейских стран в создании «инновационных супермаркетов» и использовать либо модель «тянущей технологии», либо модель «толкающей технологии» [13].

Модель «тянущей технологии» основана на поиске и разработке решений по инновационным проектам для нужд инновационного супермаркета. Поиск осуществляется с помощью многочисленных внедренческих и венчурных центров, разбросанных по всему миру и работающих по единым стандартам в тесном контакте с государством.

Модель «тянущей технологии» более успешна, чем модель «толкающей технологии», которую пытаются применить в государствах - участниках СНГ, когда технологии движутся от науки к рынку. Это обосновывается неспособностью ученых и изобретателей оценить все преимущества коммерческой продукции, созданной по их образцам, а также отсутствием у них знаний о нуждах супермаркета с его многочисленными потребностями и стандартами. В «толкающей» модели государство берет на себя риск и финансирует инновации во всех сферах экономики, что в современных условиях достаточно дефицитно для бюджета.

\section{ВЫВОДЫ}

Как показали наши исследования, инновации являются генератором для эффективного функционирования и конкурентоспособного состояния предприятия. Сегодня разработку и внедрение инноваций осуществляет менее $10 \%$ от общего числа российских предприятий, мала доля предприятий,осуществляющих инвестиции в приобретение новых знаний и технологий - 11,8\% к тому же предприятия, как белорусские, так и российские, ориентированы на заимствование готовых технологий, а не на создание новых.

Как показал сравнительный анализ, в России и в Беларуси уделяется не достаточно много внимания инновационной активности предприятий. Хотя Беларусь и уступает России по запасам нефти и газа, ее конкурентным преимуществом должен стать высокий удельный вес инновационных предприятий.

Республике Беларусь для достижения значительных экономических результатов и повышения благосостояния необходим подъём инновационной активности. Чтобы достичь намеченных целей, необходимо на макроуровне способствовать созданию институтов государственной поддержки инновационной активности (подобно европейским), и достаточно быстрыми темпами переориентировать экономику с ресурсной на инновационную.

\section{ЛИТЕРАТУРА}

1. Гальманова, Р.И. Методы оценки экономической эффективности инноваций с учетом их жизненного цикла / Р.И.Гальманова // Управление экономическими системами: электронный научный журнал, 2001. - №4 (28). - № гос.рег. статьи 0421100034.0141]. - Режим доступа :http://uecs.mcnip.ru]/ Дата доступа : 10.06.2015

2. Новиков, В.С. Инновации в туризме. - М.: ИЦ «Академия», 2007. $-208 \mathrm{c}$.

3. Никитина, О. В. Методы оценки инновационной активности предприятий: автореф. дис... канд. экон. наук. - СПб, 2007.

4. Инновационное развитие звеньев экономики: монограф. / под ред. А.А.Быкова, М.И. НоздринаПлотницкого. - Минск: изд-во «Мисанта», 2009. - 143с.

5. Экономика предприятия. Учебник под редакцией доктора экономических наук, профессора Н. А. Сафронова. - Издательство «Юристь». [Электронный ресурс]. -1998. - Режим доступа :http://bibliotekar.ru/economikapredpriyatiya-3/53.htm/ Дата доступа : 15.05.2015

6. Информационно - аналитическая записка «Об итогах социально-экономического развития Республики Беларусь за 2013 год и мерах по повышению конкурентоспособности экономики». Минск, 2014. - 49c. - С. 16.

7. ВВП России в 2014 году вырос на 0,6\%. Аналитический обзор. - [Электронный ресурс]. -2015. - Режим доступа :http://www.interfax.ru/business/421178 Дата доступа : 10.06.2015

8. Завадский, О. Всемирный банк прогнозирует рост ВВП Беларуси в 2015 году на 1,8\% / О.Завадский / Брестская газета (630) 9 - 15 января. - [Электронный ресурс]. - 2015. - Режим доступа :http://www.bg.by/ru/2_2015/economics/24676/ Дата доступа : 14.06.2015

9. Новости Беларуси - [Электронный ресурс]. - 2015. - Режим доступа :http://www.mmbank.by/about/news/novosti_belarusi/2014/pravitel_stvo_belarusi_snizilo/Дата доступа : 10.06.2015 
10. Информационно - аналитическая записка «Об итогах социально - экономического развития Республики Беларусь за I квартал 2014г., факторах, влияющих на ограничения экономического роста, и мерах по преодолению негативных тенденций для выполнения важнейших параметров прогноза на 2014

год» [Электронный ресурс]. - 2014 - Режим доступа :http://economics.basnet.by/files/Itogi_2014_kv1.pdf Дата доступа : 15.05 .2015

11. Беларусь и Россия. Статистический сборник. - [Электронный ресурс]. -1995-2013. - Режим доступа : http://www.gks.ru/bgd/regl/b14_37/Main.htm Дата доступа : 10.06.2015

12. Фоменко, О.В. Инновационное развитие компаний стран-участниц ВТО: сравнительный анализ / О.В.Фоменко // Креативная экономика, 2013. - №8(80). - с.23-30

13. Бойко, А.Н., [и др]. Опыт инновационного сотрудничества стран ЕС и СНГ / А.Н. Бойко, Г.А.Власкин, Е.Б.Ленчук, В.В.Овчинников, В.А. Цукерман. :http://www.cis.minsk.by/page.php?id=13594 Дата доступа : 15.05.2015

Статья поступила в редакииюю 16 июня 2015 года. 